\title{
Optimization of the drilling Parameters for GFRP Composite using Taguchi Technique
}

\author{
Abeer S. Eisa \\ Lecture, Production Engineering \& Mech. Design Dept., Faculty of Engineering, Menoufiya \\ University, Egypt. Drabeereisa78@yahoo.com
}

\begin{abstract}
:
The surface roughness and the delamination are important difficulties in any drilling operation of (GFRP) composite materials. Both two elements cause structural integrity reduction and poor assembly as well as the potential for long-term performance deterioration. In this research, the optimization of drilling parameters using Taguchi technique, to obtain minimum both surface roughness ( $\mathrm{Ra}$ ) and the delamination factor (df). In addition, ANOVA uses to analyze the data obtained from the experiments and determine the optimal parameters in the drilling of GFRP composite materials. The results revealed that the delamination factor (df) increases with the increase of drilling speed (2250rpm-2750rpm) and increases with the increase of the feed rate $(100 \mathrm{~mm} / \mathrm{min}$ to $125 \mathrm{~mm} / \mathrm{min}$ ). Increasing the drilling speed and reducing feed rate can reduce the delamination factor (df) and the use of high feed rate and high spindle speed can be increasing the delamination factor (df) within the limits of specified speed and feed rates. The feed rate is the more influential factor on delamination than the other parameters. The results for very low feed rate i.e. $25 \mathrm{~mm} / \mathrm{min}$ and high drilling speed $2750 \mathrm{rpm}$ show a clear decrease in surface roughness $(\mathrm{Ra})$. Feed rate and drilling speed are the more influential factors on surface roughness $(\mathrm{Ra})$ than the other parameters.

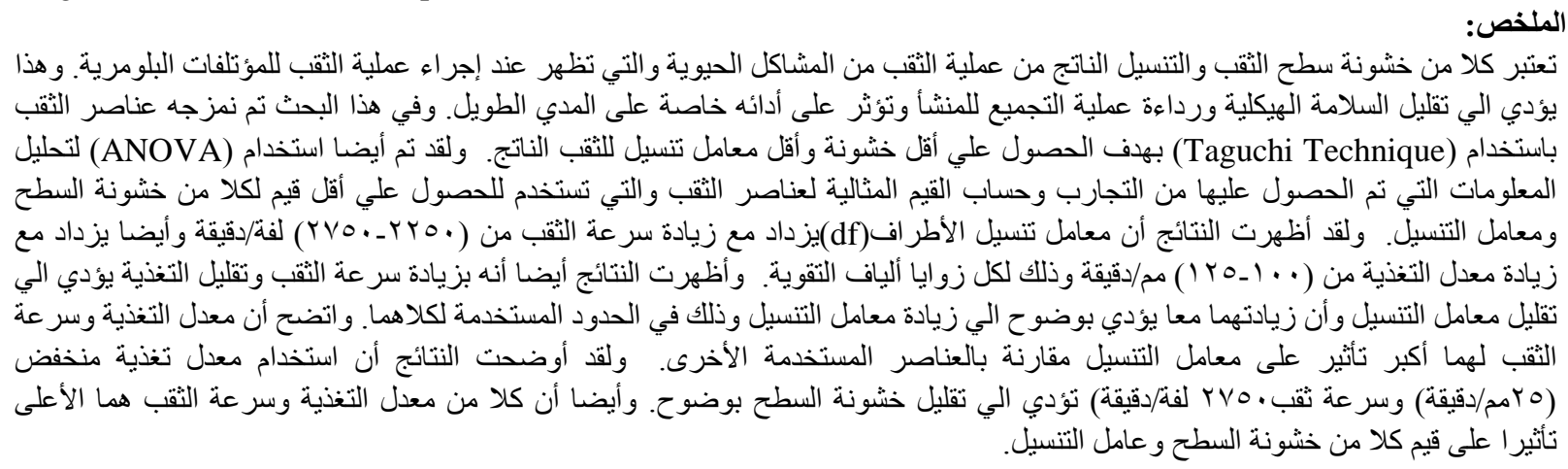

Keywords: Optimization, Taguchi Method, ANOVA, Composite Materials, GFRP, Delamination, Surface Quality, Machining processes, Fiber orientation.

\section{Introduction}

Polymer matrix composites (PMCs) are one of the commonly used composites because of their superior properties such as high strength, stiffness, and corrosion resistance. GFRPs are strong and light, showing resistance presences similar to metallic materials. In addition, it is widely used in different fields such as automotive, aircraft, aerospace and oil industries due to their specific properties.

For many purposes, which GFRPs is used, drilling is one of the widely used machining processes. Drilling of composite materials is a challenging task due to the number of problems, such as surface delamination, fiber pullout associated with the characteristics of the material and the cutting parameters that appear during the machining process. Surface roughness has a great effect on the functional properties of the product. It is an important aspect of mechanical engineering design depending on the application of the element in usage. The Friction, the wear and the power transmission depend on PMCs material surface and contact environment and due to stress condition, precision fits, smooth motion etc. Finding the rules that how process and environment 
factors influence the values of surface roughness will help to set the process parameters of the future and then improve production quality and efficiency. Thus, the optimization methods are considered being a very important tool for continual improvement of output quality in processes and for obtaining high product quality. Also, to control and optimize numerous drilling parameters. Taguchi method is a tool of discovery the best combination of an input (cutting parameters, cutting condition, work piece and cutting tool material properties) for producing a high quality of product and services. Furthermore, is use on developing the design of the manufacturing process for creating high quality product compared to statistical process control that tries to control the factors that affect the product quality. The optimization of process parameters; the feed rate, the cutting speed, the tool point angle and the chisel edge width in the drilling of glass fiber reinforced polymer (GFRP) composites using Taguchi method is presented in the work of Vinod Kumar Vankanti, Venkates warlu Ganta [1]. An L9 orthogonal array is used to study the influence of various machining parameters on the resultant hole quality. The significance of each parameter on drilling operation determined by the analysis of variance (ANOVA) test. From the results, it is obvious that the feed rate is the most significant factor influencing the thrust force followed by speed, chisel edge width and point angle.Also, the optimum process parameters of the used range in the drilling operation of GFRP composites are; the speed of $500 \mathrm{rpm}$, feed rate at $0.04 \mathrm{~mm} / \mathrm{rev}$, point angle at $90^{\circ}$ and chisel edge width of $0.8 \mathrm{~mm}$ for thrust force. Nevertheless, for the torque; the speed at $500 \mathrm{rpm}$, the feed rate of 0.06 $\mathrm{mm} / \mathrm{rev}$, point angle at $95^{\circ}$ and chisel edge width of $1.6 \mathrm{~mm}$ are found to be optimum values. Sumesh A S, Melvin Eldho Shibu [2] conducted work to optimize the process parameter such as the cutting speed, the feed, and the drill diameter by using Taguchi methods. The technique is used to obtain minimum surface roughness ( $\mathrm{Ra}$ ) of the drilled hole when used HSS twist drills. To determine the most significant control factors influencing the surface roughness, the Analysis of variance (ANOVA) is also used. The machining parameters such as cutting speed, feed rate and drill diameter are select as a control factor. The drilling parameters are optimized with respect to multiple performances to achieve a better quality of drilled holes and after nine experimental trials that the drill diameter is the most significant factor for the surface roughness. From the result analysis, it is identified that a spindle speed of $80 \mathrm{rpm}$, drill diameter of $4 \mathrm{~mm}$ and a feed rate of 0.1 $\mathrm{mm} / \mathrm{rev}$ is the optimal combination of drilling parameters that produced a high value of $\mathrm{S} / \mathrm{N}$ ratios of hole roughness. G.Srikanth Reddy, Ranjith Kumar [3] presented an experimental investigation to optimize process parameters in drilling operation of composite materials. The effect of the tool point angle, the spindle speed and the feed rate on material removal rates are studied and analyzed. Drilling operations are conducted on the carbon fiber with 6.5 and $10.2 \mathrm{~mm}$ diameter drills $\left(118^{\circ}\right.$ and $120^{\circ}$-point angles) with different machining parameters. The input parameters, which considered are; 6.5 and $10.2 \mathrm{~mm}$ diameter drill bits with $118^{\circ}$ and $120^{\circ}$ point angles, the spindle speeds 1000,1500 and 2000rpm with feed rate $30 \mathrm{~mm} / \mathrm{min}$. Different combinations from the previous parameters used to get the maximum value of MRR. From the analysis, the time taken for drilling is less for 1180 and $6.5 \mathrm{~mm}$ diameter drill and the stresses are more for 1200 angle and $6.5 \mathrm{~mm}$ diameter drill. The material removal rate increases with the increase of the used drill diameter and the spindle speed. Ilknur Çavuşoğlu, et al. [4] conducted research on the optimization of drilling parameters of glass fiber reinforced plastics via Taguchi method. The analysis and evaluation of the delamination factor to investigate in the GFRP using high precision metrology techniques. The optimum values with the minimum of delamination are determined by using Taguchi method. So, with these values in all sectors use of free of damage and delayed damage will be achieved. Rajiv Chaudhary, et al. [5] presented a work to study the critical constraints such as, the surface roughness, tolerances and nominal size for the selection criteria of the parts. While Taguchi method systematically reveals the complex, cause and evolves the relationship between design parameters along with taking consideration of performance. When using Taguchi technique the significant factors developed such as optimum machining conditions and improving performance characteristics. In addition, the multiple performance characteristics such as the tool life, the cutting force, the surface roughness as well as the overall productivity can be improved. From the analysis of the results, it is essential to determine the optimal cutting conditions for a given tool-workpiece combination. From the results, the user of large cutting speeds with smaller feed rate, good surface quality along with dimensional accuracy can be 
achieved. Amarnath R. Mundhekar, et al. [6] conducted a work on optimization of drilling process by studying the influence of various drilling parameters (spindle speed, feed rate, drill diameter, drill point angle, etc.) on the performance parameters (surface roughness, material removal rate, thrust force, etc.) during drilling process. The relationship between the input process parameters and the output responses studied in order to optimize the process parameters. The chief object of this work is to determine the region of critical process control factors. These factors are; drill diameter, material thickness and the drill point angle. This leads to desired output or responses with acceptable variations that will ensure a low cost of machining process through optimization. In addition, this may be used to face the challenge of higher productivity and quality of the product. Bala Swapna, et al. [7], investigates the optimization of drilling parameters for least surface roughness using Taguchi method. From this work, the effect of input parameters on the MRR, surface roughness, hole diameter error, burr height studied and analyzed. MRR mostly influenced by cutting speed and drill diameter. The surface roughness mainly influenced by drilling material, drill diameter and cutting speed. However, the burr height affected mainly by feed rate and cutting speed. The optimization of drilling parameters on surface roughness and material removal rate by using Taguchi method presented by S.V. Alagar samy, et al. [8]. This technique used to investigate the effects of drilling parameters such as cutting speed, feed rate and depth of cut on the resultant surface roughness and material removal rate in drilling and to find the optimal cutting parameters. A series of experiments based on L16 orthogonal array are conducted using CNC vertical machine. To calculate the most significant control factors affecting the surface roughness and material removal rate, the analyses of variances is employed. For MRR, Analysis of Variances (ANOVA- S/N ratio) showed that the depth of cut is majorly contributing of about $56.96 \%$ in obtaining optimal MRR followed by feed rate $20.11 \%$ and depth of Cut 3.56\%. But for the surface roughness, ANOVA clearly indicated that the cutting speed has a large effect in obtaining optimal surface roughness (about $28.65 \%$ ) followed by feed rate of $(10.20 \%)$ and the depth of cut of $(8.12 \%)$. K. Palanikumar [9] conducted an application of Taguchi and response surface methodologies to analyze and evaluate the surface roughness in machining glass fiber reinforced plastics by PCD tooling. The design of experiments has been directed using Taguchi's experimental design technique. The effect of the cutting process such as; cutting speed, feed rate and depth of cut on the resultant surface roughness is evaluated and the optimum cutting condition for minimizing the surface roughness is determined. In addition, a second-order response surface model for surface roughness has been developed from the observed data. From the results, the most significant machining parameter for surface roughness feed rate followed by cutting speed. The developed model can be successfully used to predict the surface roughness in the machining of GFRP composites. Verification test results revealed that the determined optimal combination of machining parameters satisfy the real requirements of the operation in the machining of GFRP composites. Murthy B.R.N., et al. [10] presented a work to optimize the influence of process parameters such as the spindle speed, the feed rate, the drill diameter, the tool point angle, and the material thickness on the generated thrust force and torque during drilling of Glass Fiber Reinforced Polymer (GFRP) composite material using solid carbide drill bit. Full Factorial Design of Experiments (DOE) has been adopted and the results indicated that the spindle speed is the chief contributing parameter for the variation in the thrust force, but drill diameter is the main contributing factor for variation in torque. The results in this work based on the preselected range values of; the spindle speed, the feed rate, the material thickness, the drill diameter and the drill point angle, and therefore, the inferences are drawn cannot be completely generalized. From the results, the thrust force significantly influenced by the spindle speed, and they are inversely proportional. Due to the use of bigger drill diameter, the thrust force increased and the cutting torque significantly influenced by drill diameter. It is obvious from the results that the thrust force and cutting torque increased with the increase in feed rate and the material thickness. The used methods indicated the values of response, through which, process parameter selection. The present research conducted on optimization of dry drilling conditions on GFRP composite laminates. Taguchi method used because it is a good tool of finding the best combination of an input (cutting parameters, cutting condition, work piece and cutting tool geometry) for producing a high quality of the product and the services. The objective of the present research is to study the influence of three sets of fiber orientation angles, HSS twist drill, five feed rates and 
five of the cutting speeds on the resultant surface roughness and delamination of drilled hole. The design of experiments has been conducted using Taguchi's experimental design technique. The effect of cutting process on the resultant surface roughness and delamination evaluated and the optimum cutting condition for minimizing the surface roughness and delamination is determined.

\section{2- Experimental Procedure \\ 2.1-Design of experiment}

Design of Experiment is a powerful approach to improve product design where it can reduce the cycle time required to develop new product or processes. Furthermore, the design of experiments (DoE) dictates a series of steps to follow for the experiment to yield an improved understanding of product or process performance. The independently controllable machining parameters which are having greater influences on the surface roughness and the delamination while drilling conditions of GFRP composite laminates are as follow, 1) the drilling speed, 2) the feed rate, 3) the fiber orientation angles ,4) the tool geometry and with fiber volume fraction ratio. These parameters and their levels are shown in Table (1).

Table (1) Parameters and their Levels.

\begin{tabular}{|c|c|c|c|c|c|c|}
\hline $\begin{array}{c}\text { Process } \\
\text { parameters }\end{array}$ & Unit & 1 & 2 & 3 & 4 & 5 \\
\hline $\begin{array}{c}\text { drilling } \\
\text { speed }\end{array}$ & $\mathrm{rpm}$ & 750 & 1250 & 1750 & $\begin{array}{c}225 \\
0\end{array}$ & 2750 \\
\hline Feed rate & $\begin{array}{c}\mathrm{mm} / \mathrm{mi} \\
\mathrm{n}\end{array}$ & 25 & 50 & 75 & 100 & 125 \\
\hline $\begin{array}{c}\text { Volume } \\
\text { fraction } \\
\text { ratio }\end{array}$ & $\%$ & 60 & 60 & 60 & 60 & 60 \\
\hline $\begin{array}{c}\text { Fiber } \\
\text { orientation } \\
\text { angles }\end{array}$ & $\begin{array}{c}\text { Degree } \\
0 / 0 / 0 / 0\end{array}$ & $\begin{array}{c}0 / 45 / 45 / \\
0\end{array}$ & $0 / 90 / 90 / 0$ \\
\hline $\begin{array}{c}\text { Used Tools } \\
\text { HSS twist drill (diameter } \varphi 8 \mathrm{~mm} \\
\left.\text { and point angle } 90^{\circ}\right)\end{array}$ \\
\hline
\end{tabular}

\section{Experimental Setup}

\subsection{Materials, Process Parameters and Tools}

In this work, glass fiber is used as reinforcement in the form of bidirectional fabric (Standard E-Glass Fiberglass) and polyester with catalyst addition as matrix for the composite material. The material used is a typical composite plate of dimensions $(200 \times 40 \times 20 \mathrm{~mm})$ with $60 \%$ fiber volume fraction ratio. The specimen is constituted by four layers with different fiber orientation angles as follow; Set (1): [/0/0/0/0], Set (2): [0/45/45/0] and Set (3): [0/90/90/0]. During the manufactured of specimens, the orientation of the fibers on the workpiece has been set. The plates fabricated by hand lay-up process followed by a cure process under constant pressure. The mechanical properties of the used composite are calculated analytically using the mixture rules. The material properties presented in Table (2).

\begin{tabular}{|c|c|c|c|c|}
\hline Material & Properties & $\begin{array}{l}\text { Sym } \\
\text { bol }\end{array}$ & Value & units \\
\hline $\begin{array}{l}\text { Glass } \\
\text { Fiber }\end{array}$ & $\begin{array}{l}\text { Elasticity } \\
\text { Modulus } \\
\text { Density } \\
\text { Poisson's } \\
\text { coefficient } \\
\end{array}$ & $\begin{array}{l}\text { Ef } \\
\rho f \\
\text { of } \\
\end{array}$ & $\begin{array}{l}76.00 \times 10^{9} \\
2.56 \times 10^{3} \\
0.22\end{array}$ & $\begin{array}{l}{\left[\mathrm{N} / \mathrm{m}^{2}\right]} \\
{\left[\mathrm{Kg} / \mathrm{m}^{3}\right]}\end{array}$ \\
\hline $\begin{array}{l}\text { Poly- } \\
\text { ester }\end{array}$ & $\begin{array}{l}\text { Elasticity } \\
\text { Modulus } \\
\text { Density } \\
\text { Poisson's } \\
\text { coefficient } \\
\end{array}$ & $\begin{array}{l}\mathrm{Em} \\
\rho \mathrm{m} \\
\mathrm{vm} \\
\end{array}$ & $\begin{array}{l}4.00 \times 10^{9} \\
1.30 \times 10^{3} \\
0.40\end{array}$ & $\begin{array}{l}{\left[\mathrm{N} / \mathrm{m}^{2}\right]} \\
{[\mathrm{Kg} / \mathrm{m} 3]}\end{array}$ \\
\hline $\begin{array}{l}\text { Composite } \\
\text { material }\end{array}$ & $\begin{array}{l}\text { Elasticity } \\
\text { Modulus of } \\
\text { Fiber } \\
\text { direction } \\
\text { Normal to } \\
\text { fiber } \\
\text { Density } \\
\text { Shear } \\
\text { Modulus } \\
\text { Poisson's } \\
\text { coefficient } \\
\text { Fiber } \\
\text { volume } \\
\text { fraction }\end{array}$ & $\begin{array}{l}\text { E11 } \\
\text { E22 } \\
\rho c \\
\text { G12 } \\
v 12 \\
\text { Vf }\end{array}$ & $\begin{array}{l}1780 \\
4.86 \times 10^{9} \\
0.28 \\
60 \%\end{array}$ & $\begin{array}{l}{\left[\mathrm{N} / \mathrm{m}^{2}\right]} \\
{\left[\mathrm{N} / \mathrm{m}^{2}\right]} \\
{\left[\mathrm{Kg} / \mathrm{m}^{3}\right]} \\
{\left[\mathrm{N} / \mathrm{m}^{2}\right]}\end{array}$ \\
\hline
\end{tabular}

\subsection{Drilling operation setup}

The Machine, which used in drilling operations, is an Extron M218, LH, CNC Machine. The feed rate and the drilling speed are controlled by a programs which written specifically for drilling of composites. Highspeed steel (HSS) tool of $\varphi 8 \mathrm{~mm}$ is use for the drilling operations. The tips of the drills ground to have drill point angles of, $\left(90^{\circ}\right)$.To prevent the effect of twist drill wear on the results; each of them is use for drilling five holes only.

\subsection{Measurement of the surface roughness and calculation of delamination factor}

The machined holes are prepared for measurements and the measurements of the surface roughness are perform using SJ-201P surface test. The measurements made after the calibration of the instrument and with the cut-off length of $(0.8 \mathrm{~mm})$ according to (ISO 4287-1997). The surface roughness of the hole is measure at entry, middle and exit of the drilled hole and the average value of surface roughness is consider for the investigation. The results of measurements are tabulate for every hole and classified all results into groups related to 
the following; the drilling speed, the feed rate and the fiber orientation angles.

The delamination factor $(d f)$ can be calculated as follows;

$d f=\mathrm{D} \max / \mathrm{D}$

Where:

$\mathrm{D} \max =$ the maximum diameter created due to delamination around the hole.

And, $\mathrm{D}=$ the hole or drill diameter.

\subsection{Experimental planning}

Taguchi parameters design begins with the selection of orthogonal array with the number of levels, which must use in this research. The drilling parameters, which effect on the resultant surface roughness and the delamination will discuss using the analysis of variance. The orthogonal array L25 for the two responses, [the surface roughness $(R a)$ and the delamination factor $(d f)]$ is presented in Table (3).

Table (3) the orthogonal array L25.

\begin{tabular}{|l|l|l|l|l|}
\hline $\mathrm{A}$ & $\mathrm{B}$ & $\mathrm{C}$ & $\mathrm{D}$ & $\mathrm{E}$ \\
\hline 1 & 1 & 1 & 1 & 1 \\
\hline 1 & 2 & 2 & 2 & 2 \\
\hline 1 & 3 & 3 & 3 & 3 \\
\hline 1 & 4 & 4 & 4 & 4 \\
\hline 1 & 5 & 5 & 5 & 5 \\
\hline 2 & 4 & 3 & 2 & 1 \\
\hline 2 & 5 & 4 & 3 & 2 \\
\hline 2 & 1 & 5 & 4 & 3 \\
\hline 2 & 2 & 1 & 5 & 4 \\
\hline 2 & 3 & 2 & 1 & 5 \\
\hline 3 & 2 & 5 & 3 & 1 \\
\hline 3 & 3 & 1 & 4 & 2 \\
\hline 3 & 4 & 2 & 5 & 3 \\
\hline 3 & 5 & 3 & 1 & 4 \\
\hline 3 & 1 & 4 & 2 & 5 \\
\hline 4 & 5 & 2 & 4 & 1 \\
\hline 4 & 1 & 3 & 5 & 2 \\
\hline 4 & 2 & 4 & 1 & 3 \\
\hline 4 & 3 & 5 & 2 & 4 \\
\hline 4 & 4 & 2 & 5 & 3 \\
\hline 5 & 4 & 5 & 1 & 2 \\
\hline 5 & 5 & 1 & 2 & 3 \\
\hline 5 & 1 & 2 & 3 & 4 \\
\hline 5 & 2 & 3 & 4 & 5 \\
\hline 5 & 3 & 2 & 4 & 5 \\
\hline
\end{tabular}

\section{Results and Discussion}

4.1. Optimization of the drilling conditions of GFRP composites

When using Taguchi method, there are three categories of quality characteristics in the analysis of the $\mathrm{S} / \mathrm{N}$ ratio, i.e., the - lower - better, the - higher better, and the - nominal - better. The $\mathrm{S} / \mathrm{N}$ ratio for each level of the process parameter compared based on the S/N analysis. Regardless of the category of the quality characteristic, a greater $\mathrm{S} / \mathrm{N}$ ratio corresponds to better quality characteristics. Then, the optimal level of the process parameters is the level with the greatest S/N ratio. Furthermore, the use of statistically significant with the $\mathrm{S} / \mathrm{N}$, the optimal combination of the process parameters can be predict. Now, a confirmation experiment is conducted to verify the optimal process parameters obtained from the parameter design. The experimental design consists of three replication. 1) The term "signal" represents the desirable value, 2) Noise (represents the undesirable value), and 3) The formulae for signal - to- noise ratio. It can be always select the largest factor level setting to optimize the quality characteristic of an experiment due to the designed formulae for the signal to noise ratio. Now, the Smaller-The-Better, which required in this research, is determined as follow;

The Signal-To-Noise ratio for the Smaller-The-Better is:

$\mathrm{S} / \mathrm{N}=-10 * \log$ (mean square of the response);

$\zeta=-10 \log \left[\frac{1}{n}\right] \sum_{i=1}^{n} y_{i}^{2} \ldots .$. for smaller the better

Where $\mathrm{n}=$ number of measurements in trial/row, in this case, $n=1,2 \ldots, 9$ and $\mathrm{Yi}$ is the ( $\mathrm{i}$ th) measured value in a run/row. $i=1,2 \ldots, 25$.

\subsection{Analysis of Variance}

\subsubsection{Analysis of Variance for the surface roughness}

Analysis of variance is a method of portioning variability into an identifiable source of variation and the associated degree of freedom in an experiment. The frequency test (F-test) is utilized in statistics to analyze the significant effects of the parameters, which form the quality characteristics. Table (3) shows the results of ANOVA analysis of $\mathrm{S} / \mathrm{N}$ ratio for the surface roughness. This analysis is carried out for a level of significance of (5\%), i. e., for (95\%) a level of confidence. The last column of the table shows the "percent "contribution $(\mathrm{P})$ of each factor as the total variation, indicating its influence on the result.

In Table (4), the F - values of the used parameters presented. Form this table, the $\mathrm{F}$ - values of drilling 
speed, feed rate and fiber orientation angles have statistical and physical significance on the surface roughness.

Table (4) Analysis of variance for surfaceroughness.

\begin{tabular}{|c|c|c|c|c|c|}
\hline Source & DF & Seq SS & MS & $\begin{array}{c}\text { F- } \\
\text { Test }\end{array}$ & P \\
\hline $\begin{array}{c}\text { Drilling } \\
\text { speed }\end{array}$ & 6 & 54.876 & 46.595 & 12.30 & 4.7 \\
\hline Feed rate & 4 & 129.667 & 16.012 & 19.27 & 30 \\
\hline $\begin{array}{c}\text { Volume } \\
\text { fraction } \\
\text { ratio }\end{array}$ & 6 & 23.099 & 5.099 & 2.30 & 50 \\
\hline $\begin{array}{c}\text { Fiber } \\
\text { orientation } \\
\text { angles }\end{array}$ & 8 & 5.825 & 1.081 & 0.80 & 5.1 \\
\hline $\begin{array}{c}\text { Used } \\
\text { Tools }\end{array}$ & 4 & 3.773 & 0.693 & 0.51 & 9.2 \\
\hline Error & 2 & 2.699 & 1.350 & -- & 7 \\
\hline Total & 24 & 227.967 & -- & -- & 100 \\
\hline
\end{tabular}

Where: DF: degree of freedom,

Seq SS: Sum square, MS: Mean square and P: Percentage of contribution.

\subsubsection{Analysis of Variance for the delamination}

In Table (5), the F - values of the used parameters presented. Form this table; it is seeming that the F values of drilling speed, feed rate and fiber orientation angles have statistical, physical significance on the delamination factor.

Table (5) Analysis of variance for delamination.

\begin{tabular}{|c|c|c|c|c|c|}
\hline Source & DF & Seq SS & MS & $\begin{array}{c}\text { F- } \\
\text { Test }\end{array}$ & P \\
\hline $\begin{array}{c}\text { drilling } \\
\text { speed }\end{array}$ & 3 & 64.376 & 50.395 & 13.30 & 5.7 \\
\hline Feed rate & 2 & 39.667 & 18.012 & 16.27 & 40 \\
\hline $\begin{array}{c}\text { Volume } \\
\text { fraction } \\
\text { ratio }\end{array}$ & 6 & 43.039 & 6.112 & 1.30 & 40 \\
\hline $\begin{array}{c}\text { Fiber } \\
\text { orientation } \\
\text { angles }\end{array}$ & 8 & 7.845 & 1.081 & 0.80 & 6.1 \\
\hline $\begin{array}{c}\text { Used } \\
\text { Tools }\end{array}$ & 4 & 2.663 & 0.234 & 0.51 & 9.2 \\
\hline Error & 1 & 3.499 & 1.340 & -- & 7 \\
\hline Total & 24 & 227.967 & -- & -- & 100 \\
\hline
\end{tabular}

Where: DF: degree of freedom, square, MS: Mean square and

Seq SS: Sum $P$ : Percentage of contribution.

\subsection{Determination of optimum factor level for the surface roughness}

Figure (1) shows five graphs, each represents the mean response and the mean $\mathrm{S} / \mathrm{N}$ ratio for the cutting speed, the feed rate, the fiber orientation angles and the volume fraction ratio. The values in the graphs have been tabulated in Tables (6, and 7), based on the $\mathrm{S} / \mathrm{N}$ ratio and ANOVA analysis. The optimum cutting conditions for the surface roughness shown in Table (5) are; A2, B5, C3, D1 and E3.

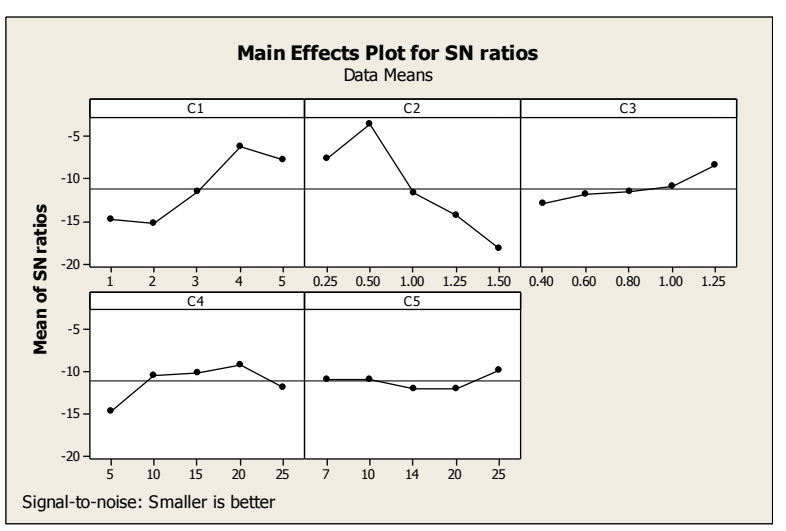

Fig. (1) Determination of optimum factor using ANOVA

Table (6) Response table for the signal to noise ratio of surface roughness

(Smaller is better) (*Optimum level).

\begin{tabular}{|c|c|c|c|c|c|}
\hline Level & $\begin{array}{l}\text { Drilling } \\
\text { speed } \\
\text { rpm (A) }\end{array}$ & $\begin{array}{c}\text { Feed } \\
\text { rate } \\
\mathrm{mm} / \mathrm{mi} \\
\mathrm{n} \\
\text { (B) }\end{array}$ & $\begin{array}{c}\text { Volume } \\
\text { fraction } \\
\text { ratio } \\
\text { (C) }\end{array}$ & $\begin{array}{l}\text { Fiber } \\
\text { orienta } \\
\text { tion } \\
\text { angles } \\
\text { (D) }\end{array}$ & $\begin{array}{l}\text { Used } \\
\text { Tools } \\
\text { (E) }\end{array}$ \\
\hline 1 & -14.822 & -7.731 & -12.952 & $\begin{array}{c}- \\
14.690 \\
*\end{array}$ & -10.873 \\
\hline 2 & $\begin{array}{c}- \\
15.237 *\end{array}$ & -3.629 & -11.931 & $\begin{array}{c}- \\
10.518\end{array}$ & 10.978 \\
\hline 3 & -11.566 & -11.651 & $\begin{array}{c}- \\
13.157 *\end{array}$ & $\begin{array}{c}- \\
10.100\end{array}$ & $\begin{array}{c}- \\
12.075 \\
*\end{array}$ \\
\hline 4 & -6.244 & -14.395 & -10.911 & -9.178 & -12.002 \\
\hline 5 & -7.872 & $18.336^{*}$ & -8.407 & $\begin{array}{c}- \\
11.828\end{array}$ & -9.814 \\
\hline Delta & 8.993 & 14.707 & 8.929 & 5.513 & 2.261 \\
\hline Rank & 2 & 1 & 3 & 4 & 5 \\
\hline
\end{tabular}


Table (7) Response table for means surface roughness.

\begin{tabular}{|c|c|c|c|c|c|}
\hline $\begin{array}{c}\text { Leve } \\
1\end{array}$ & $\begin{array}{c}\text { Drillin } \\
\mathrm{g} \text { speed } \\
\mathrm{rpm} \\
(\mathrm{A})\end{array}$ & $\begin{array}{c}\text { Feed } \\
\mathrm{mm} / \mathrm{mi} \\
\mathrm{n}\end{array}$ & $\begin{array}{c}\text { Volum } \\
\mathrm{e} \\
\text { fraction } \\
\text { ratio } \\
(\mathrm{C})\end{array}$ & $\begin{array}{c}\text { Fiber } \\
\text { orientatio } \\
\mathrm{n} \text { angles } \\
(\mathrm{D})\end{array}$ & $\begin{array}{c}\text { Used } \\
\text { Tool } \\
\mathrm{s} \\
(\mathrm{E})\end{array}$ \\
\hline 1 & 4.168 & 2.559 & 1.631 & 3.824 & $\begin{array}{c}2.96 \\
5\end{array}$ \\
\hline 2 & 7.935 & 1.867 & 3.373 & 2.568 & $\begin{array}{c}4.14 \\
4\end{array}$ \\
\hline 3 & 3.368 & 5.017 & 3.175 & 1.509 & $\begin{array}{c}2.28 \\
4\end{array}$ \\
\hline 4 & 5.023 & 2.389 & 7.227 & 6.736 & $\begin{array}{c}6.64 \\
4\end{array}$ \\
\hline 5 & 2.996 & 4.658 & 3.806 & 8.999 & $\begin{array}{c}8.45 \\
3\end{array}$ \\
\hline 6 & & & 1.627 & & \\
\hline 7 & & & 7.363 & & \\
\hline Delta & 2.939 & 7.791 & 5.004 & 4.088 & 1.13 \\
\hline Rank & 3 & 1 & 2 & 4 & 5 \\
\hline
\end{tabular}

\subsection{Determination of the optimum}

\section{factor level for the delamination}

Figure (2) shows five graphs, each represents the mean response and the mean $\mathrm{S} / \mathrm{N}$ ratio for one of the used parameters. The values in the graphs have been tabulated in Tables (8, and 9), based on the $\mathrm{S} / \mathrm{N}$ ratio and ANOVA analysis. The optimum cutting conditions for the surface roughness shown in Table (8) are; A4, B1, C3, D5 and E2.

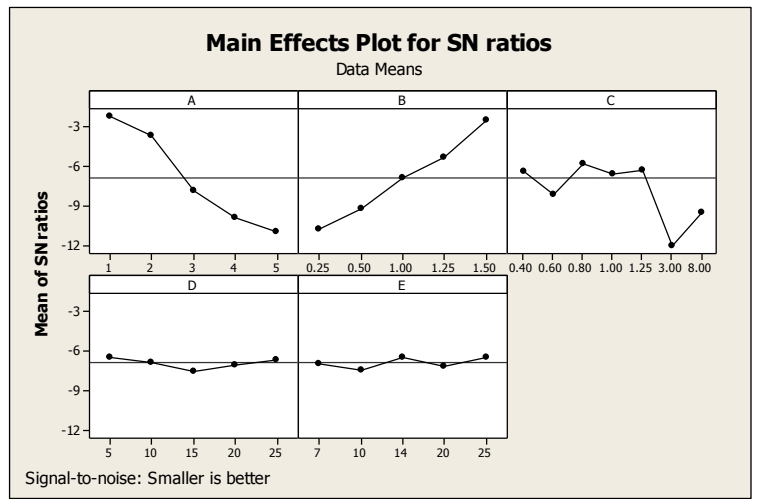

Figure (2) Determination of optimum factor using ANOVA
Table (8) Response table for signal to noise ratio of delamination (Large is better) $\left({ }^{*}\right.$ Optimum level)

\begin{tabular}{|c|c|c|c|c|c|}
\hline Level & $\begin{array}{c}\text { Drilling } \\
\text { speed } \\
\text { rpm } \\
(\mathrm{A})\end{array}$ & $\begin{array}{c}\text { Feed } \\
\mathrm{mm} / \mathrm{min}\end{array}$ & $\begin{array}{c}\text { Volume } \\
\text { fraction } \\
\text { ratio } \\
(\mathrm{C})\end{array}$ & $\begin{array}{c}\text { Fiber } \\
\text { orientation } \\
\text { angles (D) }\end{array}$ & $\begin{array}{c}\text { Used } \\
\text { Tools } \\
(\mathrm{E})\end{array}$ \\
\hline 1 & 5.128 & $4.339^{*}$ & 1.631 & 2.444 & 1.335 \\
\hline 2 & 3.455 & 1.557 & 2.553 & 1.778 & $3.664^{*}$ \\
\hline 3 & 2.368 & 2.227 & $2.475^{*}$ & 1.219 & 1.224 \\
\hline 4 & $6.223^{*}$ & 1.559 & 6.337 & 7.446 & 5.664 \\
\hline 5 & 2.496 & 3.558 & 4.806 & $8.669^{*}$ & 5.113 \\
\hline 6 & & & 1.527 & & \\
\hline 7 & & & 6.223 & & \\
\hline Delta & 2.439 & 1.791 & 4.004 & 4.088 & 1.139 \\
\hline Rank & 2 & 1 & 3 & 4 & 5 \\
\hline
\end{tabular}

Table (9) Response table for means delamination.

\begin{tabular}{|c|c|c|c|c|c|}
\hline Level & $\begin{array}{c}\text { Drilling } \\
\text { speed } \\
\text { rpm } \\
(\mathrm{A})\end{array}$ & $\begin{array}{c}\text { Feed } \\
\mathrm{mm} / \mathrm{min}\end{array}$ & $\begin{array}{c}\text { Volume } \\
\text { fraction } \\
\text { ratio } \\
(\mathrm{C})\end{array}$ & $\begin{array}{c}\text { Fiber } \\
\text { orientation } \\
\text { angles (D) }\end{array}$ & $\begin{array}{c}\text { Used } \\
\text { Tools } \\
(\mathrm{E})\end{array}$ \\
\hline 1 & 1.245 & 2.559 & 1.631 & 3.824 & 2.965 \\
\hline 2 & 8.124 & 1.867 & 3.373 & 2.568 & 4.144 \\
\hline 3 & 3.12 & 5.017 & 3.175 & 1.509 & 2.284 \\
\hline 4 & & 2.389 & 7.227 & 6.736 & 6.644 \\
\hline 5 & 2.996 & 4.658 & 3.806 & 8.999 & 8.453 \\
\hline 6 & & & 1.627 & & \\
\hline 7 & & & 7.363 & & 1.139 \\
\hline Delta & 2.939 & 7.791 & 5.004 & 4.088 & 5 \\
\hline Rank & 3 & 1 & 2 & 4 & \\
\hline
\end{tabular}

In Table (10) the experimental results and predicted values of the surface roughness ( $\mathrm{Ra})$ presented. The deviation between the experimental results and the predicted value is between $(0.0$ and $0.1 \mu \mathrm{m})$. 
Table (10) Measured and predicted surface roughness of (ANOVA) technique.

\begin{tabular}{|c|c|c|c|}
\hline $\begin{array}{l}\text { Readin } \\
\mathrm{g} \\
\text { numbe } \\
\mathrm{r}\end{array}$ & $\begin{array}{l}\text { Surface } \\
\text { roughness } \\
\text { of } \\
\text { experiment } \\
\text { al }(\mathrm{Ra})\end{array}$ & $\begin{array}{c}\text { Predicte } \\
\text { d by } \\
\text { ANOV } \\
\text { A }\end{array}$ & $\begin{array}{c}\text { Deviatio } \\
\mathrm{n}\end{array}$ \\
\hline 1 & 1.16 & 1.17 & -0.01 \\
\hline 2 & 1.19 & 1.20 & 0.01 \\
\hline 3 & 1.22 & 1.22 & 0 \\
\hline 4 & 1.25 & 1.24 & 0.01 \\
\hline 5 & 1.26 & 1.25 & 0.01 \\
\hline 6 & 1.36 & 1.35 & 0.01 \\
\hline 7 & 1.09 & 1.09 & 0 \\
\hline 8 & 1.10 & 1.11 & -0.01 \\
\hline 9 & 1.12 & 1.13 & -0.01 \\
\hline 10 & 1.14 & 1.15 & -0.01 \\
\hline 11 & 1.15 & 1.16 & -0.01 \\
\hline 12 & 1.16 & 1.16 & 0 \\
\hline 13 & 1.13 & 1.12 & 0.01 \\
\hline 14 & 1.16 & 1.15 & 0.01 \\
\hline 15 & 1.19 & 1.20 & -0.01 \\
\hline 16 & 1.22 & 1.23 & -0.01 \\
\hline 17 & 1.23 & 1.22 & 0.01 \\
\hline 18 & 1.16 & 1.17 & -0.01 \\
\hline
\end{tabular}

\begin{tabular}{|c|c|c|c|}
\hline \hline 9 & 1.19 & 1.20 & -0.01 \\
\hline 20 & 1.22 & 1.23 & -0.01 \\
\hline 21 & 1.25 & 1.25 & 0 \\
\hline 22 & 1.26 & 1.25 & 0.01 \\
\hline 23 & 1.34 & 1.35 & -0.01 \\
\hline 24 & 1.09 & 1.09 & 0 \\
\hline 25 & 1.25 & 1.26 & -0.01 \\
\hline
\end{tabular}

In Table (11), the experimental results and the predicted values of the delamination factor presented using (ANOVA) technique. The deviation between the experimental results and the predicted value is between $(0.0$ and 0.1$)$.

Table (11) Measured and predicted delamination of (ANOVA) technique.

\begin{tabular}{|c|c|c|c|}
\hline $\begin{array}{c}\text { Readin } \\
\mathrm{g} \\
\text { numbe } \\
\mathrm{r}\end{array}$ & $\begin{array}{c}\text { Delaminatio } \\
\mathrm{n} \\
\text { experiment } \\
\mathrm{al}(d f)\end{array}$ & $\begin{array}{c}\text { Predicte } \\
\mathrm{d} \text { by } \\
\text { ANOV } \\
\mathrm{A}\end{array}$ & $\begin{array}{c}\text { Deviatio } \\
\mathrm{n}\end{array}$ \\
\hline 1 & 1.13 & 1.14 & -0.01 \\
\hline 2 & 1.16 & 1.15 & 0.01 \\
\hline 3 & 1.19 & 1.20 & 0.01 \\
\hline 4 & 1.22 & 1.23 & 0.01 \\
\hline 5 & 1.25 & 1.25 & 0 \\
\hline 6 & 1.34 & 1.35 & 0.01 \\
\hline 7 & 1.07 & 1.09 & 0 \\
\hline 8 & 1.09 & 1.11 & -0.01 \\
\hline \hline
\end{tabular}




\begin{tabular}{|c|c|c|c|}
\hline 9 & 1.10 & 1.13 & -0.01 \\
\hline 10 & 1.12 & 1.11 & -0.01 \\
\hline 11 & 1.14 & 1.13 & -0.01 \\
\hline 12 & 1.12 & 1.13 & 0.01 \\
\hline 13 & 1.10 & 1.11 & 0.01 \\
\hline 14 & 1.13 & 1.13 & 0.01 \\
\hline 15 & 1.16 & 1.15 & -0.01 \\
\hline 16 & 1.19 & 1.20 & -0.01 \\
\hline 17 & 1.22 & 1.22 & 0.01 \\
\hline 18 & 1.13 & 1.14 & -0.01 \\
\hline 9 & 1.16 & 1.17 & -0.01 \\
\hline 20 & 1.19 & 1.20 & -0.01 \\
\hline 21 & 1.22 & 1.22 & 0 \\
\hline 22 & 1.25 & 1.25 & 0 \\
\hline 23 & 1.22 & 1.21 & -0.01 \\
\hline 24 & 1.07 & 1.07 & 0 \\
\hline 25 & 1.09 & 1.10 & -0.01 \\
\hline
\end{tabular}

\section{The discussion}

Taguchi technique and ANOVA used to obtain minimum both of the surface roughness $(\mathrm{Ra})$ and delamination factor $(d f)$. The results obtained has been calculated and plotted as a response curves when they change from one level to another and evaluated in a standard steps as discussed. The response curves are the average value of the characteristic and average $\mathrm{S} / \mathrm{N}$ values versus level of the drilling parameters. The response curves used to analyze the parametric influence on the selected quality characteristics.

The ANOVA classifies the significant parameters and quantifies their effect on the selected quality characteristics. The $\mathrm{S} / \mathrm{N}$ response curve used to keep in the selection of optimal level of response process parameters for individual quality characteristics. From the previous results, the optimum values for the surface roughness $(\mathrm{Ra})$ and the delamination factor $(d f)$ are presented in Table (12).

Table (12) the optimum values for the Surface roughness $(\mathrm{Ra})$ and Delamination factor $(d f)$.

\begin{tabular}{|l|c|c|}
\hline Used parameters & $\mathrm{Ra}$ & $\boldsymbol{d} \boldsymbol{f}$ \\
\hline Cutting speed rpm (A) & $15.237^{*}$ & $6.223^{*}$ \\
\hline Feed mm/min(B) & $18.336^{*}$ & $4.339^{*}$ \\
\hline Volume fraction ratio (C) & $13.157^{*}$ & $2.475^{*}$ \\
\hline $\begin{array}{l}\text { Fiber orientation angles } \\
\text { (D) }\end{array}$ & $14.690^{*}$ & $8.669^{*}$ \\
\hline Used Tools (E) & $12.075^{*}$ & $3.664^{*}$ \\
\hline
\end{tabular}

\section{The conclusions}

This research has presented the optimization of drilling parameters using Taguchi technique, to obtain the minimum of both surface roughness (Ra) and the delamination factor $(d f)$. From the accurately analysis of the results, it can be concluded that:

1-The analysis of the results is carried out using Taguchi's orthogonal array and the analysis of variance. The optimum levels of the cutting parameters on the drilling induced minimum of both surface roughness $(R a)$ and the delamination factor $(d f)$ is determined by using ANOVA.

2-The delamination factor $(d f)$ is increased with the increase of the cutting speed (2250rpm-2750rpm) and increases with feed rate $(100 \mathrm{~mm} / \mathrm{min}$ to $125 \mathrm{~mm} / \mathrm{min}$ ).

3 -The results for very low feed rate i.e. $25 \mathrm{~mm} / \mathrm{min}$ and high cutting speed $2750 \mathrm{rpm}$ show a clear decrease in surface roughness $(R a)$.

4- The higher values of the delamination factor $(d f)$ at the cutting speed $2750 \mathrm{rpm}$ may be due to; when 
the drill speed increases, the thrust force increases and severe heat generation in the drilling area. As a result, fiber cutting becomes harder for the cutting edges of the drill and the drilling thrust force increases further causing more delamination.

5-The higher values of the delamination factor $(d f)$ at the the feed rate $25 \mathrm{~mm} / \mathrm{min}$ may be due the increase of generated heat between the tool and hole wall and transferred to the laminate in the drilling area and causes local thermal destruction of the work piece with undesirable results on delamination.

6- The results of ANOVA reveal that the feed rate is the main cutting parameter, which has greater influence on the delamination factor.

7- Predicted values of the delamination at optimized process parameters are in good agreement with the test results.

8- The feed rate is the more influential factor on delamination factor $(d f)$ than the other parameters.

9- The feed rate and the cutting speed are the more influential factors on the surface roughness (Ra) than the other parameters.

10- Higher cutting speed (2750 rpm), low fiber orientation $[0 / 0 / 0 / 0]$ and low feed rate $(25 \mathrm{~mm} / \mathrm{min})$ are suitable for machining (GFRP) to get a good surface roughness of drilled hole for the used tool.

\section{References}

1-Vinod Kumar Vankanti, Venkates warlu Ganta, "Optimization of process parameters in drilling of GFRP composite using Taguchi method", $\mathrm{j}$ m a t. te c h n o $1.2014,3(1)$, pp35-41.

2-Sumesh A S, Melvin Eldho Shibu, "Optimization of drilling parameters for minimum surface roughness using Taguchi method", International Conference on Emerging Trends in Engineering \& Management (ICETEM-2016), IOSR Journal of Mechanical and Civil Engineering (IOSR-JMCE) eISSN: 2278-1684,p-ISSN: 2320-334X, pp 12-20.

3- G.Srikanth Reddy, Ranjith Kumar, "Experimental Investigation to optimize process parameters in drilling operation for composite materials", International Journal of Engineering and Advanced Research Technology (IJEART) ISSN: 2454-9290, Volume-2, Issue-8, August 2016.

4-İlknur Çavuşoğlu, Mustafa Çakir, Numan M. Durakbasa, Eva Maria Walcher, "The optimization of drilling parameters of Glass Fiber reinforced Plastics via Taguchi method", Multi Science - XXX. Micro CAD International Multidisciplinary Scientific Conference University of Miskolc, Hungary, 21-22 April 2016, ISBN 978-963-358-113-1.

5-Rajiv Chaudhary, M. S. Ranganath, R. C. Singh, and Vipin, "Experimental Investigations and Taguchi Analysis with drilling operation: A Review", International Journal of Innovation and Scientific
Research ISSN 2351-8014 Vol. 13 No. 1 Jan. 2015, pp. 126-135.

6-Amarnath R. Mundhekar, Subhash R. Jadhav, "Optimization of drilling process parameters: A Review", International Journal for Research in Applied Science \& Engineering Technology (IJRASET), Volume 3 Issue II, February 2015 ISSN: 2321-9653.

7-BALA SWAPNA, D. DHARMA, "Optimization of drilling parameters for minimum surface roughness using Taguchi method", International Journal of Research in Science \& Engineering, Volume: 2 Issue: 5, e-ISSN: 2394-8299.

8-S.V. ALAGARSAMY, S. AROCKIA VINCENT SAGAYARAJ, P. RAVEENDRAN, "Optimization of drilling process parameters on surface roughness \& material removal rate by using Taguchi method", International Journal of Engineering Research and General Science, Volume 4, Issue 2, March-April, 2016, ISSN 2091-2730.

9-K. Palanikumar, "Application of Taguchi and response surface methodologies for surface roughness in machining Glass Fiber reinforced Plastics by PCD tooling", Int J Adv. Manuf Technol (2008) 36:19-27.

10-Murthy B.R.N., Lewlyn L.R. Rodrigues and Anjaiah Devineni, "Process parameters optimization in GFRP drilling through Integration of Taguchi and Response Surface Methodology", Research Journal of Recent Sciences, Vol. 1(6), 7-15, June (2012), ISSN 2277-2502, Res. J. Recent Sci. 